\title{
The Effects of Some Seed Priming Treatments on Germination and Seedling Development in Wheat
}

\author{
Tulay Elmas \\ Canakkale Onsekiz Mart University, School of Graduate Studies, \\ Subdivision of Biology, 17020, Canakkale, Turkey \\ E-mail: tulaybayrakelmas3@gmail.com \\ Okan Acar \\ Canakkale Onsekiz Mart University, Faculty of Science and Arts, Department of Biology, \\ Subdivision of Botany, 17020, Canakkale, Turkey \\ E-mail: oacar@comu.edu.tr
}

\begin{abstract}
Drought stress has negative effects on plant metabolism and growth. Seed-priming is one of the ways used to strengthen crop plants at the seed stage against drought stress. In this study, the physiological effects of seed-priming $(1,12,24$, and 48 hours $)$ and foliar treatments of $\mathrm{H}_{2} \mathrm{O}_{2}(50 \mu \mathrm{M})$ and GR24 (20 $\mu \mathrm{M}$ ) on 21-day-old wheat seedlings (drought-sensitive Triticum aestivum cv. 95 and drought-tolerant cv. Tosunbey) were studied. The plant samples were used to determine the total chlorophyll content, total protein amount, root and stem length, seedling weight, and specific leaf area. Our results showed that only GR24 increased growth in the Tosunbey variety with seed priming. On the other hand, foliar GR24 was effective in both varieties against the detrimental effect of PEG-induced osmotic stress, while foliar $\mathrm{H}_{2} \mathrm{O}_{2}$ treatment was effective only in the Tosunbey variety. Generally, it has been determined that the GR24 application supports the growth in both varieties, while the $\mathrm{H}_{2} \mathrm{O}_{2}$ treatment increases the growth only in drought-tolerant wheat variety.
\end{abstract}

Keywords: Wheat, Drought stress, Seed-priming, GR24, $\mathrm{H}_{2} \mathrm{O}_{2}$, germination, growth.

DOI: $10.7176 / J S T R / 7-05-01$

\section{Introduction}

Abiotic (drought, salinity, temperature, etc.) and biotic (viruses, parasites, etc.) stress factors reduce the crop yield in agriculture by limiting the growth and development of plants (Kaur et al., 2008; Baky et al., 2016). However, the stress tolerance of plants varies depending on the severity of the stress. Stresstolerant plants that can cope with the increase in stress can survive, while stress-sensitive plants can die. Drought stress has negative effects on plant metabolism and growth and causes serious yield losses in grain production in the world. One of the first responses of plants under water scarcity is to close their stomata to conserve water. In this condition, disruption of gas balance and photosynthetic electron flow results in an imbalance in photosynthesis. One of the earliest signals of drought in plants is the formation of Reactive Oxygen Species (ROS) that alter enzyme activities (Laxa et al., 2019). However, excessive ROS accumulation due to insufficient antioxidant defense capacity causes oxidative stress in plants (Apel and Hirt 2004, Abid et al., 2018, Hasanuzzaman et al., 2018).

ROS concentration increases in plant cells under mild and/or severe stress conditions and these can disrupt metabolism by damaging lipids, proteins, and DNA in the cell. Plant cells are protected from these harmful effects of ROS with the help of antioxidant defense system (AOS) (Asada, 2006). It consists of enzymatic (APX, Ascorbate peroxidase; CAT, Catalase; SOD, Superoxide dismutase; GR, Glutathione reductase) and non-enzymatic antioxidants (tocopherols, carotenoids, water-soluble reductants) (Fazeli et al., 2007). The activity of AOS in stress tolerance is regarded as a selective criterion for reducing yield loss due to stress, especially in the production of agricultural plants.

1 I P a g e

www.iiste.org 
Wheat is a strategic culture plant produced for food in many countries of the world (FAO 2018). Since it is rich in mineral substances, vitamin B and micronutrients, it meets most of the nutrient and energy needs of the global population (Cummins and Thomson, 2009). Drought conditions drastically reduce photosynthesis, metabolic processes, biomass, and yield in wheat. On the other hand, drought stress responses in wheat vary at morphological, physiological, molecular, and biochemical levels (Liu et al., 2019). It has been shown that inhibition caused by drought in the amount of chlorophyll, relative water content, shoot and root length in durum wheat decreases with the addition of foliar Silicon (Othmani et al., 2020). In addition, it was determined that the rosehip extract treatment in two wheat varieties with different tolerance to drought increased the antioxidant capacity through different antioxidant enzymes (Baltacier, 2019).

To prevent the decrease in product yield caused by stress factors, new stress-resistant varieties are being developed. In this context, priming treatments include some preliminary applications to reveal the stress tolerance potential of existing varieties. Currently, various priming techniques are applied from farm to industrial level for better crop yield (Figure 1, Haider et al., 2019). Hydro-priming revitalizes seeds soaked in sterile water at the appropriate temperature and ensures a robust crop formation, especially in tropical regions. Osmo-priming provides control of radicle growth due to water absorption in seeds incubated in a salt and polyethylene glycol (PEG) solution. Thus, the seeds protect from low external water potential and synchronized germination. Chemical priming and biopriming are used specifically to provide nutrients to seeds and protect them from any disease attack (Saboor et al., 2019). Seed priming improves drought stress tolerance by increasing the membrane stability, improving plant water condition and chlorophyll content, enhancing germination under normal and stressful conditions. It causes early and uniform germination due to the increased synthesis of metabolites related to germination. These applications can be carried out both at the seed and seedling stage (Saboor et al., 2019). It has been reported that the treatments of salicylic acid (SA) and thiourea (TU) to wheat increase the grain yield under water scarcity conditions (Yadav et al., 2020). On the other hand, drought priming with PEG 3000 (20\%) increases the drought tolerance of wheat, but this requires abscisic acid (ABA) and jasmonic acid (JA) (Wang et al., 2021). In addition, drought priming in the early growing stage of wheat increases drought tolerance by removing ABA and $\mathrm{H}_{2} \mathrm{O}_{2}$ (Wang et al., 2020). Finally, the treatment of polyamines (PAs) as seed priming or foliar treatment to wheat seedlings decreases lipid peroxidation and ROS concentration and increases CAT activity under drought stress. Thus, PAs have been shown to improve chloroplast content and membrane stability in wheat (Hassan et al., 2020).

Strigolactones (SL), a phytohormone, have important functions around the root, including drought tolerance. On the other hand, they promote the symbiotic relationship between plants and soil microorganisms. In addition, they provide the germination of parasitic plant seeds (Kohlen et al.2011). SL treatment has been shown to increase plant resistance under drought conditions (Min et al., 2019; Sedaghat et al., 2020). It has been determined that SL pre-treatments in wheat and sand lily have a promoting role in salt tolerance by stimulating AOS against salt stress (Özel, 2018; Önay, 2019). It has also been reported that the treatment of GR24, a synthetic SL, has a protective effect on plant cells against drought stress (Min et al., 2019).

Hydrogen peroxide is produced in many organelles in the plant cell during photosynthetic electron transport chain and respiration (Foyer et al.1997). Therefore, high $\mathrm{H}_{2} \mathrm{O}_{2}$ accumulation are lethal to plant cells due to its toxic nature. However, it has also been shown that $\mathrm{H}_{2} \mathrm{O}_{2}$ in non-toxic concentrations can act as a signal molecule in protecting plants against biotic and abiotic stress (Caverzan et al.2016; Küçükkarakaş, 2017; Arıcan, 2019). $\mathrm{H}_{2} \mathrm{O}_{2}$ can spread across the cell membrane and be transported to other compartments where they can function as signal molecules or be destroyed (Caverzan et al.2016). On the other hand, it has also been shown that $\mathrm{H}_{2} \mathrm{O}_{2}$ pretreatment can be effective in reducing the harmful effects of drought stress in wheat and rice (Shan et al., 2018; Sohag et al., 2020).

In this study, the physiological effects of $\mathrm{H}_{2} \mathrm{O}_{2}$, GR24 (synthetic SL), and PEG 3000 (\%20) on seed germination and seedling development in two wheat varieties (drought sensitive-Triticum aestivum cv. Sultan-95 and drought tolerant-cv. Tosunbey) were investigated.

2| P a g e www.iiste.org 


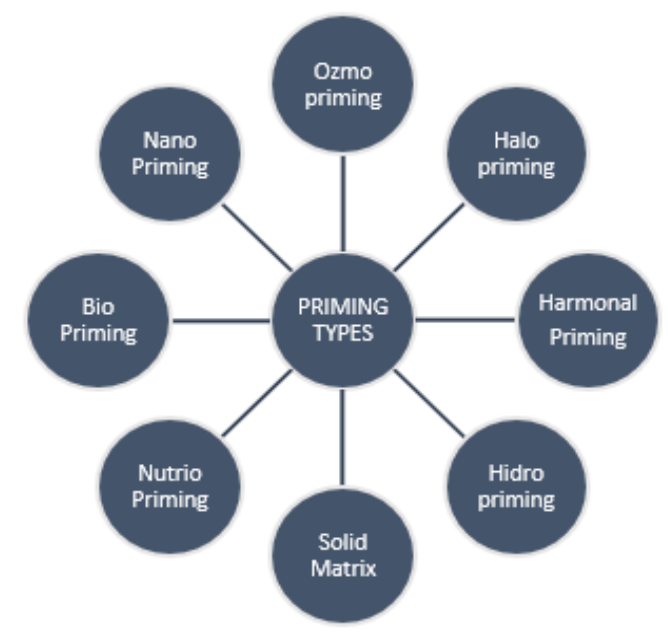

Figure 1. Priming Types (Haider et al.,2019)

\section{Materials and Methods}

\subsection{Plant Material}

In this study drought sensitive-cv. Sultan-95 and drought tolerant-cv. Tosunbey varieties of Triticum aestivum L. (Poaceae) were used. The seeds of Sultan-95 were obtained from Eskişehir Geçit Kuşağ Agricultural Research Institute and the seeds of Tosunbey from Ankara Field Crops Central Research Institute. Wheat seeds were sterilized by soaking in 5\% sodium hypochlorite solution for 5 minutes and washing with sterile distilled water. The seeds germinated by keeping them in moist filter papers for 3 days were then transferred to petri dishes and pots containing perlite. Wheat seedlings were grown in the plant growth cabinet at $22-24{ }^{\circ} \mathrm{C}$ in the $16: 8 \mathrm{~h}$ light/dark photoperiod. Wheat seedlings in pots were irrigated with Hoagland nutrient solution (100\%) for 21 days (Steward, 1983).

\subsection{Priming Treatments}

$\mathrm{H}_{2} \mathrm{O}_{2}(50 \mu \mathrm{M})$ and GR24 $(20 \mu \mathrm{M})$ priming treatments were treatment to sterile wheat seeds in petri dishes for 1, 12, 24 and 48 hours. After the seeds were washed with distilled water, they were planted on petri dishes moistened with distilled water and their germination was followed for 7 days. At the end of the experiment, the seedlings were harvested, and these samples were used to determine the total chlorophyll content, total protein amount, root and shoot length, seedling weight (biomass), germination $(\%)$ and specific leaf area.

$\mathrm{H}_{2} \mathrm{O}_{2}(50 \mu \mathrm{M})$ and GR24 $(20 \mu \mathrm{M})$ priming treatments were carried out by leaf spraying on 21 -day-old wheat seedlings grown in pots containing perlite. Osmotic stress mediated drought stress was started with the Hoagland solution containing PEG 3000 (20\%) at $48 \mathrm{~h}$ after other priming treatments. Leaf samples were collected from wheat seedlings on the $7^{\text {th }}$ and $14^{\text {th }}$ days following the drought treatment and were used to determine the total chlorophyll content, total protein amount, root and shoot length, seedling weight and specific leaf area.

\subsection{Physiological and Biochemical Parameters}

\subsubsection{Root-Shoot Length}

The lengths of the root and shoot parts of the plants were measured with a ruler.

\subsubsection{Chlorophyll Analysis}

Total chlorophyll amounts of leaf samples were measured with chlorophyll meter (Minolta, SPAD502) (Peryea and Kammereck, 1997). Data were made in 15 replicates on different leaves in the plant groups.

\subsubsection{Determination of Seedling Weight}

Seedling weights were determined by weighing on a precision scale (gr). In the petri experiment, the weight of 10 seedlings from each group was weighed in a way that all repeats from each group were taken.

3 I P a g e www.iiste.org 


\subsubsection{Determination of Germination Percentage}

At the end of the experiment, it was determined by the ratio of germinated seed to the total number of seeds in petri dishes (\%) (Zhang et al., 2020).

\subsubsection{Determination of Specific Leaf Area (SLA)}

Specific leaf area was calculated using the leaf photos of wheat seedlings in the Image J program. Then the samples are dried in an oven at $70^{\circ} \mathrm{C}$ for $24 \mathrm{~h}$ and weighed on a precision scale. SLA is calculated by the formula (Wilson et al. 1999): SLA = Area $\left(\mathrm{cm}^{2}\right) /$ Dry weight $\left(\mathrm{mg}^{-1}\right)$

\subsubsection{Total Protein Amount}

Tissue samples were homogenized with $50 \mathrm{mM}$ Na-P (pH: 7.8 and $1 \mathrm{mM}$ EDTA) buffer and then centrifuged at $10000 \mathrm{rpm}$. The supernatants obtained after centrifugation are mixed with protein reagent containing $0.1 \mathrm{~g}$ of Coomassie Brilliant Blue G $250,50 \mathrm{~mL}$ of ethanol and $100 \mathrm{~mL}$ of orthophosphoric acid in the tube. Sample protein content is obtained by calculating the absorbance at 595 $\mathrm{nm}$ in the spectrophotometer $(\mathrm{mg} / \mathrm{mL})$ in the protein standard graph (Bradford, 1976).

\subsubsection{Statistical analysis}

The data were made with Tukey test using one-way analysis of variance (ANOVA). SPSS (Statistical Package for the Social Sciences, version 20.0) program was used for statistical analysis.

\section{Results and Discussion \\ 3.1 Petri Experiment}

\subsubsection{Root-Shoot Length}

Root length increased 38\% with GR24 in Tosunbey with $1 \mathrm{~h}$ seed priming treatment compared to control. In Sultan-95, the increases with GR24 and $\mathrm{H}_{2} \mathrm{O}_{2}$ treatments were determined as $19 \%$ and $25 \%$, respectively. While the shoot length increased by $12 \%$ in Tosunbey variety with $\mathrm{H}_{2} \mathrm{O}_{2}$ treatment, a decrease of $4.5 \%$ and $9 \%$ was determined with GR24 and $\mathrm{H}_{2} \mathrm{O}_{2}$ treatment, respectively, in Sultan-95 variety compared to the control (Figure 2a).

The $12 \mathrm{~h}$ seed priming treatment increased the root length in both varieties compared to the control. These increases are $19.5 \%$ and $24 \%$, respectively, in the Tosunbey variety with GR24 and $\mathrm{H}_{2} \mathrm{O}_{2}$ treatments, while in the Sultan-95 variety it is $33 \%$ and $18 \%$. Shoot length increased $16 \%$ with $\mathrm{H}_{2} \mathrm{O}_{2}$ treatment in Tosunbey variety compared to control, while it decreased by 19\% in Sultan-95 compared to control with $\mathrm{H}_{2} \mathrm{O}_{2}$ treatment (Figure $2 b$ ).

$24 \mathrm{~h} \mathrm{GR} 24$ and $\mathrm{H}_{2} \mathrm{O}_{2}$ treatments increased root length by $19 \%$ and $14 \%$, respectively, in Tosunbey variety compared to control. Interestingly, root length increased 1.7 times higher than the control with GR24 treatment in Sultan-95 variety. In this variety, $\mathrm{H}_{2} \mathrm{O}_{2}$ treatment increased the root length by $22 \%$. Shoot length has increased with both treatments in Tosunbey variety. These increases were determined as $25 \%$ and $20 \%$ for GR24 and $\mathrm{H}_{2} \mathrm{O}_{2}$ treatments, respectively. In Sultan-95 variety, shoot length increased by $9.5 \%$ with the treatment of GR24 and decreased by $8 \%$ with $\mathrm{H}_{2} \mathrm{O}_{2}$ (Figure 2c).

While 48 h GR24 treatment decreased the root length by $16 \%$ in Tosunbey cultivar, it increased $9.7 \%$ with $\mathrm{H}_{2} \mathrm{O}_{2}$ treatment. In Sultan-95 variety, root length increased with both treatments. These increases were determined as $34 \%$ and $53 \%$, respectively, for GR24 and $\mathrm{H}_{2} \mathrm{O}_{2}$ treatments compared to the control. Shoot length is increased in both varieties compared to the control in all treatments. These increases were found $11 \%$ and 1.7 times for GR24 and $\mathrm{H}_{2} \mathrm{O}_{2}$ treatments in Sultan-95, respectively (Figure 2d).

\subsubsection{Total Chlorophyll Content}

Total chlorophyll content increased by $1-4 \%$ in both treatment groups with $1,12,24 \mathrm{~h}$ treatments, while GR2 4 and $\mathrm{H}_{2} \mathrm{O}_{2}$ pre-treatments decreased by $14 \%$ and $9 \%$, respectively, in $48 \mathrm{~h}$ of treatment in Tosunbey (Figure 3a).

In Sultan-95 variety, total chlorophyll content decreased with 12, 24 and $48 \mathrm{~h}$ treatments compared to the control. These reductions were $37 \%$ and $25 \%$ for $12 \mathrm{~h} \mathrm{GR24}$ and $\mathrm{H}_{2} \mathrm{O}_{2}$ priming, and $21 \%$ and $13 \%$ for $24 \mathrm{~h}$, respectively. $1 \mathrm{~h}$ of GR24 and $\mathrm{H}_{2} \mathrm{O}_{2}$ treatment did not change the amounts of chlorophyll (Figure 3b). 

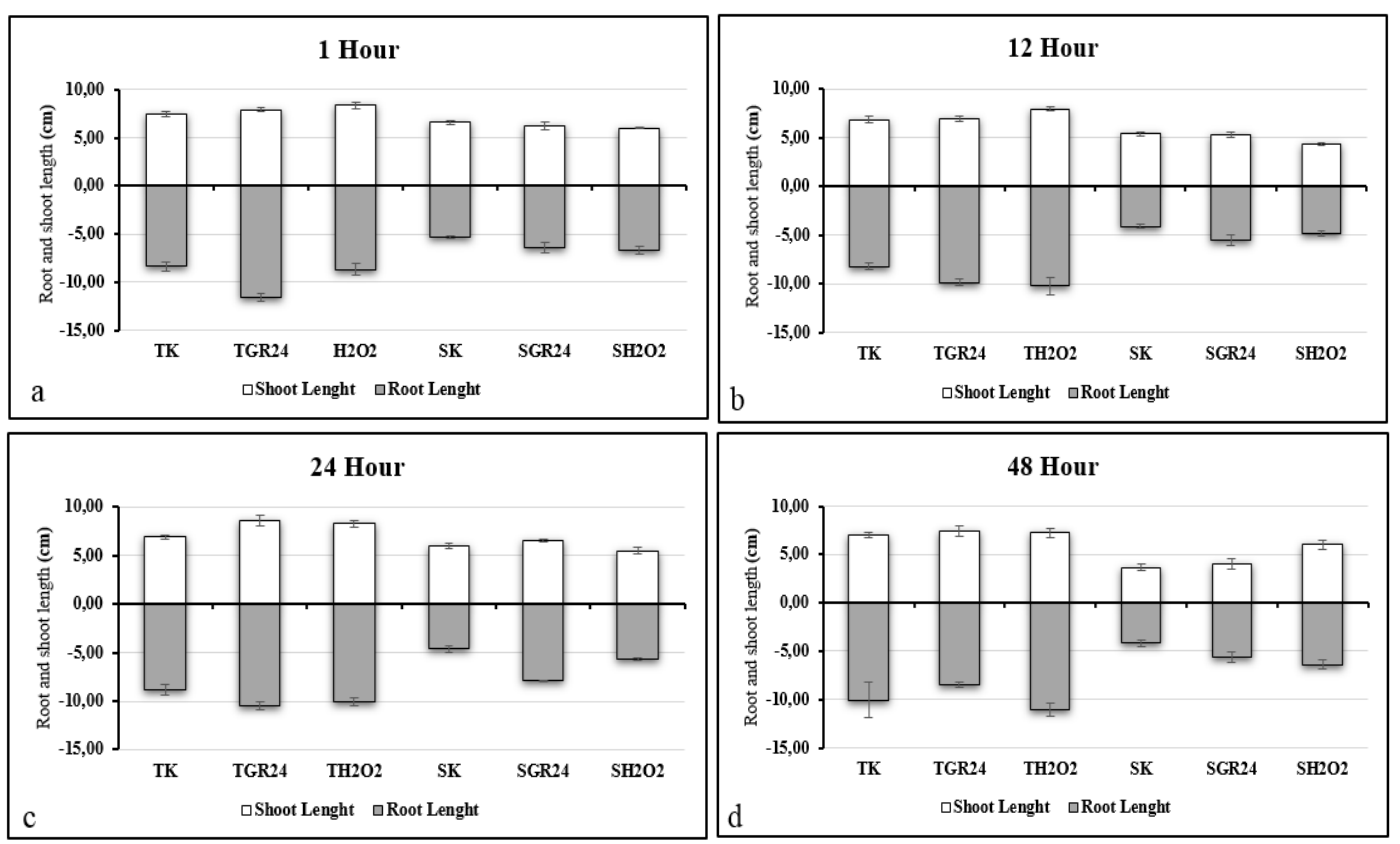

Figure 2. Effects of GR24 and $\mathrm{H}_{2} \mathrm{O}_{2}$ seed priming on root and shoot length in $7 \mathrm{~d}$ wheat seedlings. (a: 1 h, b: 12 h, c: 24 h, d: 48 h, TK: Tosunbey control, TGR24: Tosunbey GR24, $\mathrm{TH}_{2} \mathrm{O}_{2}$ : Tosunbey $\mathrm{H}_{2} \mathrm{O}_{2}$, SK: Sultan-95 control, SGR24: Sultan-95 GR24, $\mathrm{SH}_{2} \mathrm{O}_{2}$ : Sultan-95 $\mathrm{H}_{2} \mathrm{O}_{2}$ ).

\subsubsection{Seedling Weight (Biomass)}

In Tosunbey variety, seedling weight increased with $1 \mathrm{~h}$ and $12 \mathrm{~h}$ priming in both treatment groups. These increases are $15 \%$ and $13 \%$, respectively, in the GR24 group compared to the control. In the $24 \mathrm{~h}$ treatment of this variety, a 10\% decrease was detected in the GR24 group compared to the control, while an increase of $7.5 \%$ was found in the $\mathrm{H}_{2} \mathrm{O}_{2}$ group. In $48 \mathrm{~h}$ treatments, it was followed by a $9.5 \%$ decrease in the GR24 group and a 10\% increase in the $\mathrm{H}_{2} \mathrm{O}_{2}$ group. As a result, $\mathrm{H}_{2} \mathrm{O}_{2}$ priming increased biomass in all treatments compared to control, while GR24 treatment increased with only $1 \mathrm{~h}$ and $12 \mathrm{~h}$ priming (Figure 4a).

In Sultan-95 variety, $1 \mathrm{~h}$ and $12 \mathrm{~h} \mathrm{H}_{2} \mathrm{O}_{2}$ priming reduced biomass by $18 \%$ and $10 \%$, respectively, compared to control. Conversely, seedling weight increased by $25 \%$ and $16 \%$ in $24 \mathrm{~h}$ treatments of GR24 and $\mathrm{H}_{2} \mathrm{O}_{2}$, while it was $12 \%$ and $16 \%$ in $48 \mathrm{~h}$ treatments, respectively. As a result, $1 \mathrm{~h}$ and $12 \mathrm{~h}$ treatments of this variety decreased biomass, while $24 \mathrm{~h}$ and $48 \mathrm{~h}$ treatments increased (Figure $4 \mathrm{~b}$ ).
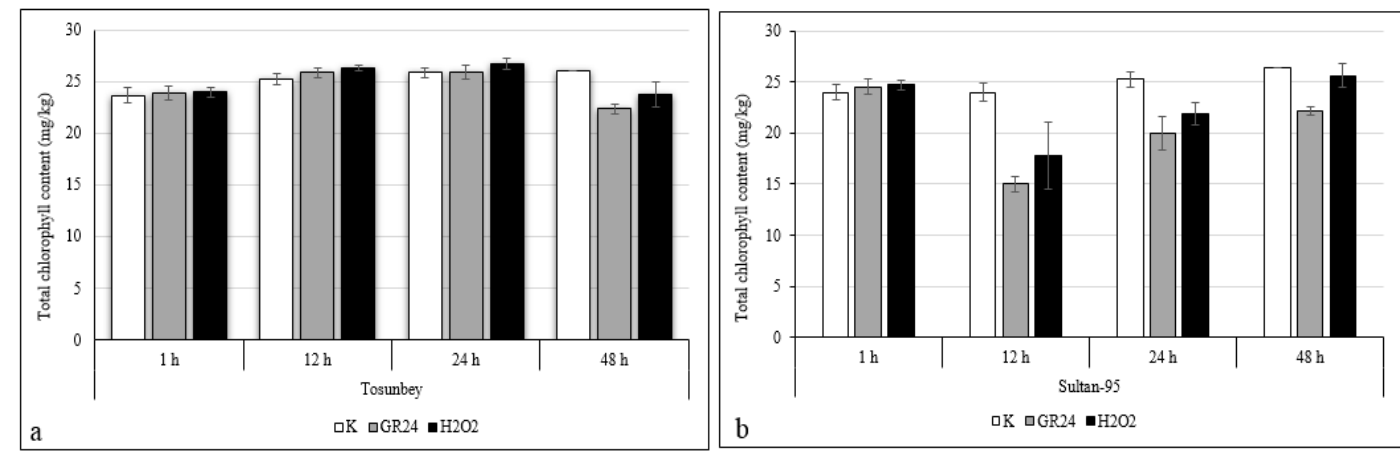

Figure 3. Effects of GR24 and $\mathrm{H}_{2} \mathrm{O}_{2}$ seed priming on total chlorophyll content in $7 \mathrm{~d}$ wheat seedlings, a: Total chlorophyll content of Tosunbey variety, b: Total chlorophyll content of Sultan-95 variety (1 h, 12 h, 24 h, 48 h: priming times, K: Control, GR24: GR24 treatment, $\mathrm{H}_{2} \mathrm{O}_{2}: \mathrm{H}_{2} \mathrm{O}_{2}$ treatment). 

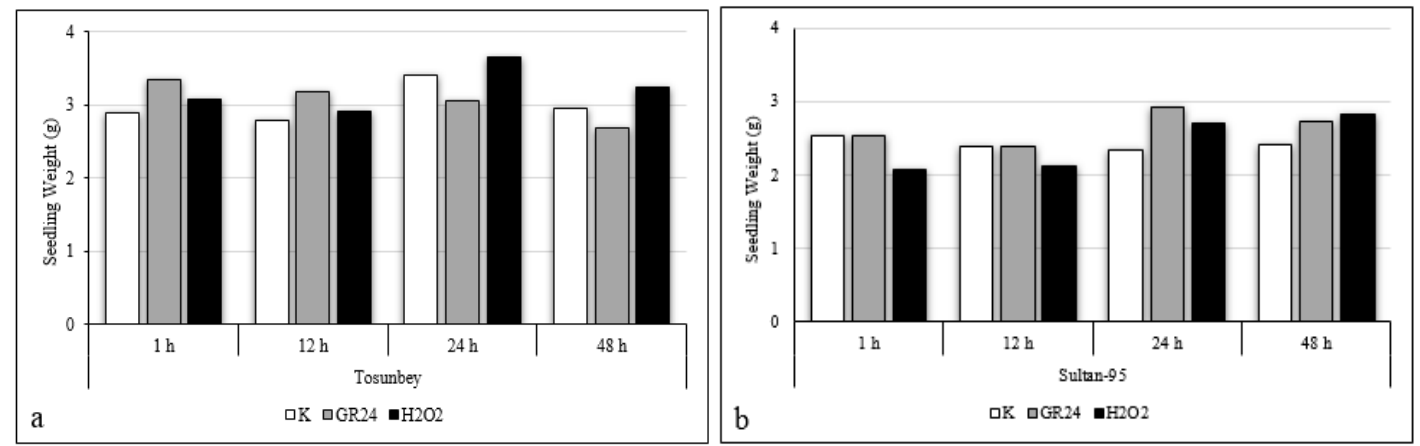

Figure 4. Effects of GR24 and $\mathrm{H}_{2} \mathrm{O}_{2}$ seed priming on seedling weight (biomass) in $7 \mathrm{~d}$ wheat seedlings, a: cv. Tosunbey, b: cv. Sultan-95 (1 h, 12 h, 24 h, 48 h; priming times; K: Control, GR24: GR24 treatment, $\mathrm{H}_{2} \mathrm{O}_{2}: \mathrm{H}_{2} \mathrm{O}_{2}$ treatment).

\subsubsection{Germination Percentage (\%)}

In Tosunbey cultivar, all seeds in both groups were germinated in $1 \mathrm{~h}$ priming. On the other hand, germination decreased in all treatments of 12, 24 and $48 \mathrm{~h}$. While these decreases were $19 \%$ in $12 \mathrm{~h}$ $\mathrm{H}_{2} \mathrm{O}_{2}$ treatment compared to control, it was determined as $14 \%$ in $24 \mathrm{~h} \mathrm{GR} 24$ treatment (Figure 5a).

In Sultan- 95 variety, $1 \mathrm{~h}$ treatment decreased the germination percentage by $4 \%$ and $14 \%$ compared to the control for GR24 and $\mathrm{H}_{2} \mathrm{O}_{2}$ priming, respectively. The $12 \mathrm{~h}$ treatment decreased the germination by $10 \%$ in both priming treatments. Interestingly, while $24 \mathrm{~h}$ treatment of GR24 decreased germination by $4 \%$, all seeds were germinated with the $12 \mathrm{~h}$ treatment decreased the germination by $10 \%$ in both priming treatments. Germination decreased by 19\% with GR24 treatment in $48 \mathrm{~h}$ treatments (Figure $5 b)$.
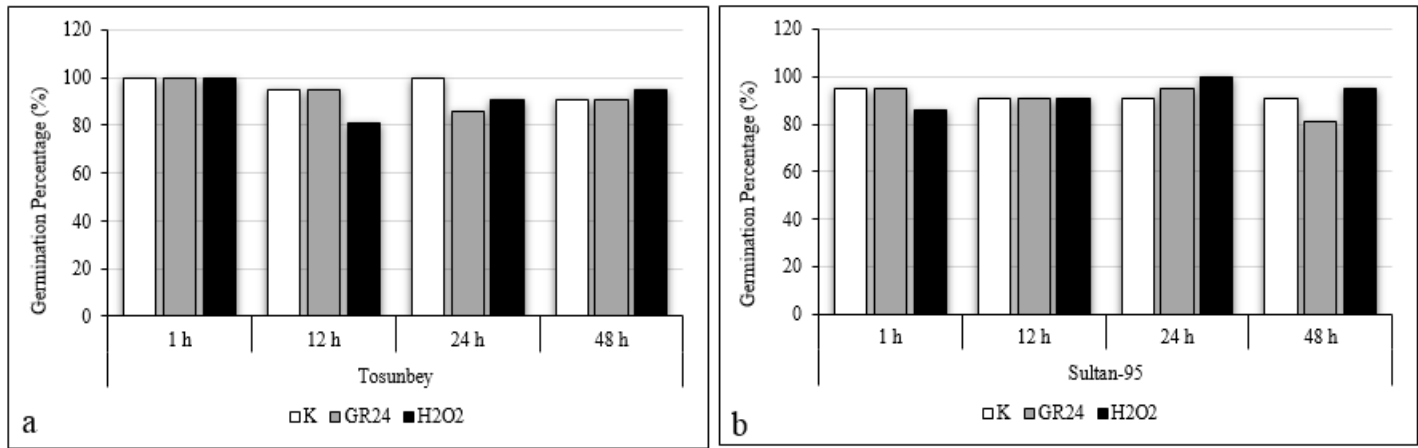

Figure 5. Effects of GR24 and $\mathrm{H}_{2} \mathrm{O}_{2}$ seed priming on germination in 7d wheat seedlings, a: cv. Tosunbey, b: cv. Sultan-95 (1 h, 12 h, 24 h, 48 h; priming times; K: Control, GR24: GR24 treatment, $\mathrm{H}_{2} \mathrm{O}_{2}: \mathrm{H}_{2} \mathrm{O}_{2}$ treatment).

\subsubsection{Specific Leaf Area (SLA)}

Specific leaf area increased by $30 \%$ and $20 \%$, respectively, with $1 \mathrm{~h}$ and $24 \mathrm{~h}$ GR24 priming in Tosunbey compared to the control and decreased with the other $12 \mathrm{~h}$ and $24 \mathrm{~h}$ treatments. $\mathrm{H}_{2} \mathrm{O}_{2}$ application has increased SLA in all treatments compared to control in this type. These increases were determined as $40 \%, 14 \%, 13 \%$ and $9 \%$ for 1, 12, 24, and $48 \mathrm{~h}$, respectively (Figure 6a). SLA decreased in Sultan-95 variety, except for $48 \mathrm{~h} \mathrm{H}_{2} \mathrm{O}_{2}$ priming. Accordingly, while SLA decreased by 19-30\% with GR24 priming treatments, it was found to decrease $7-45 \%$ with $\mathrm{H}_{2} \mathrm{O}_{2}$ priming treatments (Figure 6b).

\subsubsection{Total Protein Amount}

In Tosunbey variety, 1,12 and $24 \mathrm{~h} \mathrm{GR} 24$ and $\mathrm{H}_{2} \mathrm{O}_{2}$ treatments significantly increased the total protein amounts compared to the control. These increases were determined as the lowest $11 \%(12 \mathrm{~h})$ and the highest 45\% (24 h) for GR24, while the lowest 15\% (12 h) and the highest 39\% (24 h) for $\mathrm{H}_{2} \mathrm{O}_{2}$ (Figure 7a).

6| P a g e

www.iiste.org 
In Sultan-95 variety, GR24 treatments significantly increased the total protein amount by $14 \%$ compared to the control with only $12 \mathrm{~h}$ application. Other GR24 applications did not change the total protein content. All applications except $12 \mathrm{~h}$ of $\mathrm{H}_{2} \mathrm{O}_{2}$ application significantly increased the total protein content of this variety by 11-30\% compared to the control. The highest increase was observed in $24 \mathrm{~h}$ application (Figure 7b).

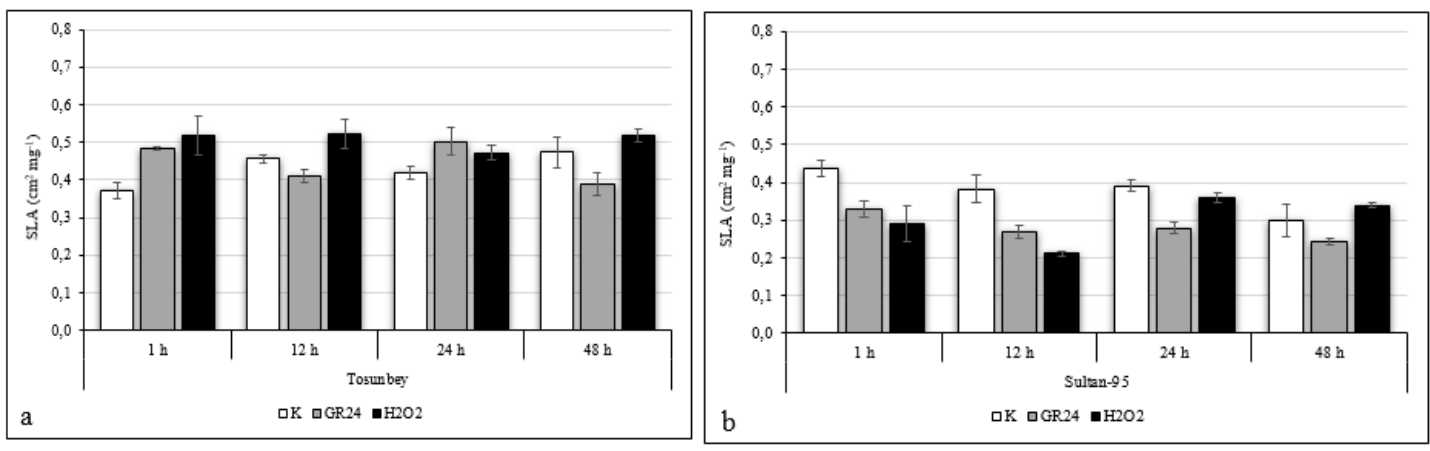

Figure 6. Effects of GR24 and $\mathrm{H}_{2} \mathrm{O}_{2}$ seed priming on SLA in 7d wheat seedlings, a: cv. Tosunbey, b: cv. Sultan-95 (1 h, 12 h, 24 h, 48 h; priming times; K: Control, GR24: GR24 treatment, $\mathrm{H}_{2} \mathrm{O}_{2}: \mathrm{H}_{2} \mathrm{O}_{2}$ treatment).
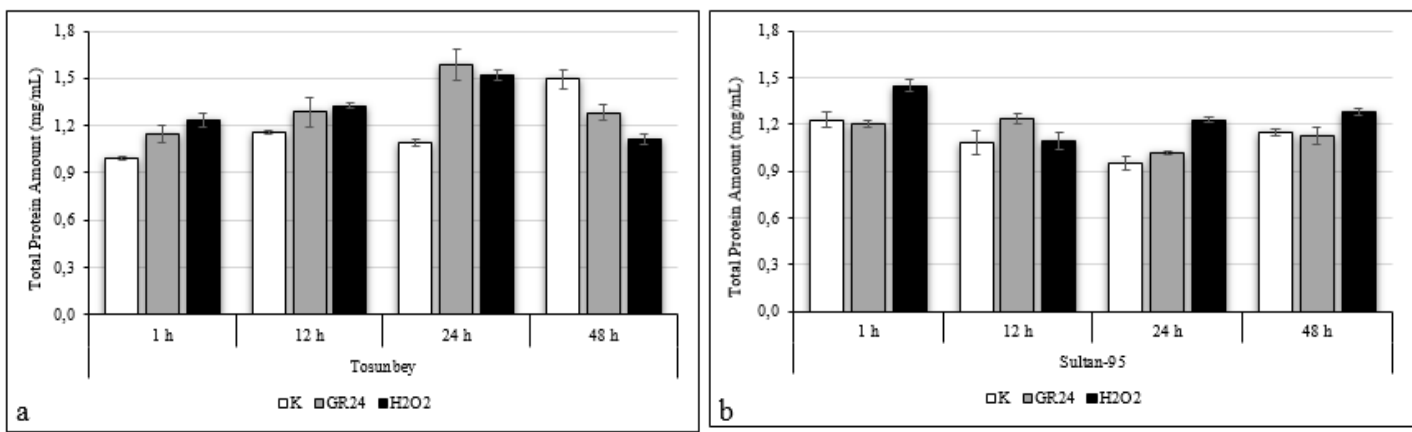

Figure 7. Effects of GR24 and $\mathrm{H}_{2} \mathrm{O}_{2}$ seed priming on total protein amounts in $7 \mathrm{~d}$ wheat seedlings, a: cv. Tosunbey, b: cv. Sultan-95 (1 h, 12 h, 24 h, 48 h; priming times; K: Control, GR24: GR24 treatment, $\mathrm{H}_{2} \mathrm{O}_{2}: \mathrm{H}_{2} \mathrm{O}_{2}$ treatment).

\subsection{Pot Experiment}

\subsubsection{Root-Shoot Length}

In the control group [PEG (-)] shoot length decreased by 3\% with GR24 treatment on the 7th day compared to the control in Tosunbey variety, while it increased by $1.2 \%$ with $\mathrm{H}_{2} \mathrm{O}_{2}$ treatment. In Sultan95 variety, shoot length decreased by $4-6 \%$ with all treatments. Root length increased by $13 \%$ on the 7 th day with GR24 treatment in Tosunbey variety and decreased by $20 \%$ with $\mathrm{H}_{2} \mathrm{O}_{2}$ treatment. In Sultan-95 variety, root length increased by $13 \%$ on the 7 th day with GR24 treatment and decreased by $5 \%$ with $\mathrm{H}_{2} \mathrm{O}_{2}$ treatment. Shoot length of Tosunbey variety decreased by $7 \%$ compared to control with $\mathrm{H}_{2} \mathrm{O}_{2}$ treatment on the 14th day. In Sultan-95, shoot length increased by $7 \%$ with GR24 priming and $4 \%$ with $\mathrm{H}_{2} \mathrm{O}_{2}$ priming compared to the control. Root length increased by $9 \%$ with GR24 and $\mathrm{H}_{2} \mathrm{O}_{2}$ on the $14^{\text {th }}$ day in Tosunbey variety. In Sultan-95 variety, root length increased by $7 \%$ on the $14^{\text {th }}$ day with all treatments.

At the end of the experiment, it was determined that drought treatment [PEG $(+)$ ] decreased shoot length in all priming treatments in both varieties. While these decreases are $6-10 \%$ on the $7^{\text {th }}$ and $14^{\text {th }}$ days in Tosunbey variety, it is $10-16 \%$ on the $7^{\text {th }}$ day in Sultan 95 variety and $1-4 \%$ at the end of the trial. It was determined that the root length did not show a significant change on the $7^{\text {th }}$ day with priming treatments in Tosunbey and decreased by $8 \%$ with $4 \% \mathrm{H}_{2} \mathrm{O}_{2}$ treatment on the $14^{\text {th }}$ day with GR24 treatment. In Sultan-95 variety, GR24 treatment decreased the root length by $21-24 \%$ and $\mathrm{H}_{2} \mathrm{O}_{2}$ treatment by $11-15 \%$ during the trial (Figure 8 ). 

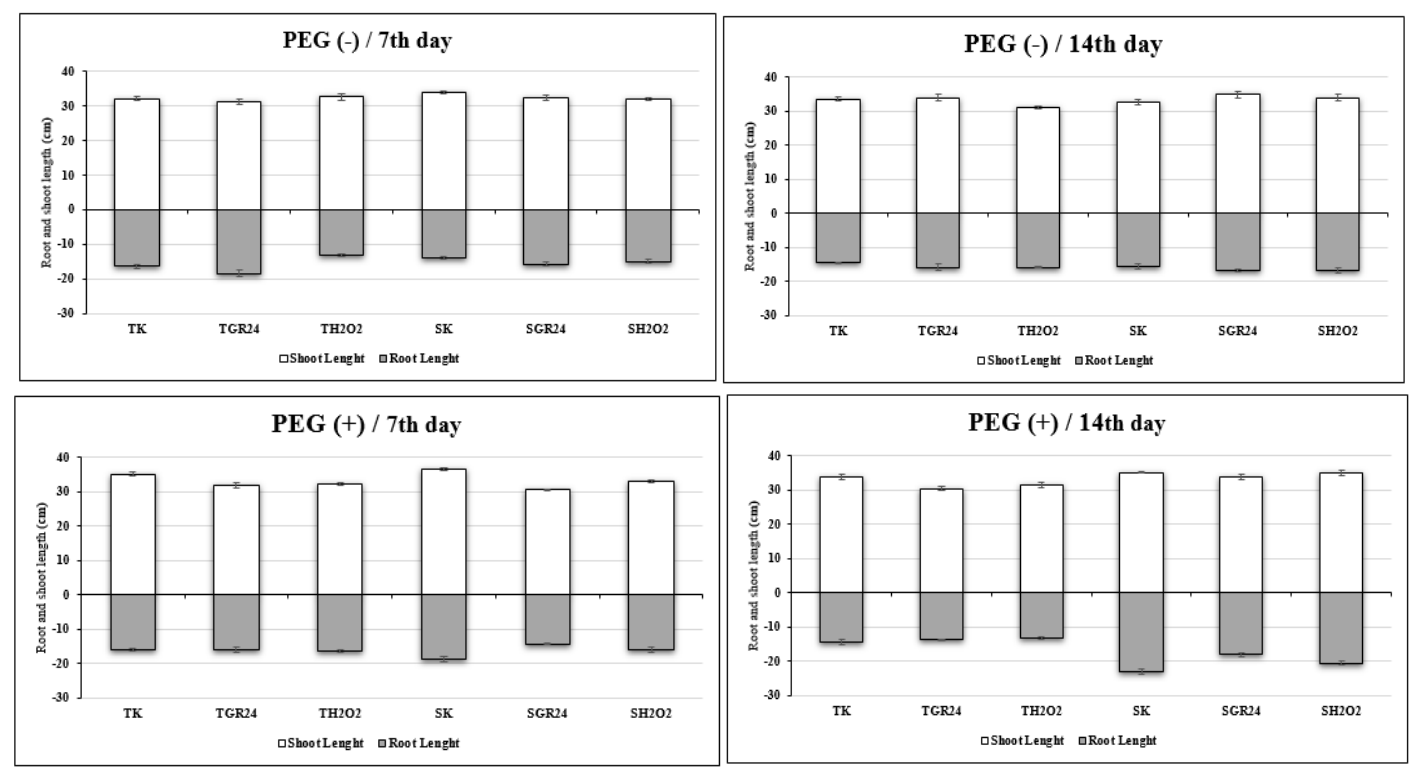

Figure 8. Effects of foliar GR24 and $\mathrm{H}_{2} \mathrm{O}_{2}$ treatments on root and shoot lengths in 7d- and14d-old wheat seedlings under control [PEG (-)] and drought treatment [PEG (+)] conditions (TK: Tosunbey control, TGR24: Tosunbey GR24, $\mathrm{TH}_{2} \mathrm{O}_{2}$ : Tosunbey $\mathrm{H}_{2} \mathrm{O}_{2}$, SK: Sultan-95 control, SGR24: Sultan-95 GR24, $\mathrm{SH}_{2} \mathrm{O}_{2}$ : Sultan-95 $\mathrm{H}_{2} \mathrm{O}_{2}$ ).

\subsubsection{Total Chlorophyll Amount}

The amount of total chlorophyll increased with GR24 priming at the end of the experiment under control and drought conditions in both varieties. These increases were $15 \%$ in Tosunbey variety in PEG (-) group on the $14^{\text {th }}$ day and $7 \%$ in PEG (+) group. In Sultan-95 variety, these increases are 7\% and $10 \%$, respectively (Figure 9a-b). In contrast, $\mathrm{H}_{2} \mathrm{O}_{2}$ priming decreased the total chlorophyll content at the end of the experiment in both varieties under control and drought conditions. While these decreases were $2 \%$ in Tosunbey variety in PEG (-) group on the $14^{\text {th }}$ day, it was $7 \%$ in PEG (+) group. In Sultan95 variety, these decreases are $8 \%$ and $7 \%$, respectively (Figure 9c-d).

\subsubsection{Seedling Weight (Biomass)}

GR24 priming increased biomass in the PEG (-) group on the $7^{\text {th }}$ and $14^{\text {th }}$ day, respectively, by $14 \%$ and $20 \%$ compared to the control in Tosunbey variety. On the contrary, drought treatment decreased biomass by $27 \%$ and $14 \%$, respectively, compared to control. In the GR24 priming Sultan 95, the biomass was decreased at the end of the experiment under control and drought conditions. These decreases were $36 \%$ and $52 \%$, respectively, in the PEG (-) group on the $7^{\text {th }}$ and $14^{\text {th }}$ days, and $6 \%$ and $13 \%$ in the PEG (+) group, respectively (Figure 10a-b).

$\mathrm{H}_{2} \mathrm{O}_{2}$ priming reduced biomass at the end of the experiment under control and drought conditions in both varieties, except for the $7^{\text {th }}$ day of Tosunbey variety. At the end of the experiment, these decreases were determined as $18 \%$ in Tosunbey in PEG (-) group and 8\% in PEG (+) group. In Sultan-95 variety, these decreases were $52 \%$ and $57 \%$, respectively, on the $7^{\text {th }}$ day, and $17 \%$ and $10 \%$ at the end of the experiment (Figure 10c-d).

\subsubsection{Specific Leaf Area (SLA)}

It was determined that SLA decreased by $5 \%$ and $3 \%$ on the $7^{\text {th }}$ and $14^{\text {th }}$ day of the experiment under control and drought conditions with GR24 priming in Tosunbey variety. It was determined that there was no significant change in the control group due to GR24, and in the drought group, SLA increased by $9 \%$ during the experiment in Sultan-95 (Figure 11a-b).

Interestingly, $\mathrm{H}_{2} \mathrm{O}_{2}$ priming increased SLA by $11 \%$ in the control group of Tosunbey during the experiment. However, the drought treatment in this variety has not changed the SLA. In Sultan-95, $\mathrm{H}_{2} \mathrm{O}_{2}$ priming decreased SLA by $4 \%$ on the 7 th day in the control group and increased it by $4 \%$ at the end of the experiment. The drought treatment decreased the SLA of this variety by $8 \%$ and $3 \%$ on the $7^{\text {th }}$ and $14^{\text {th }}$ days, respectively (Figure 11c-d).

8| P a g e

www.iiste.org 

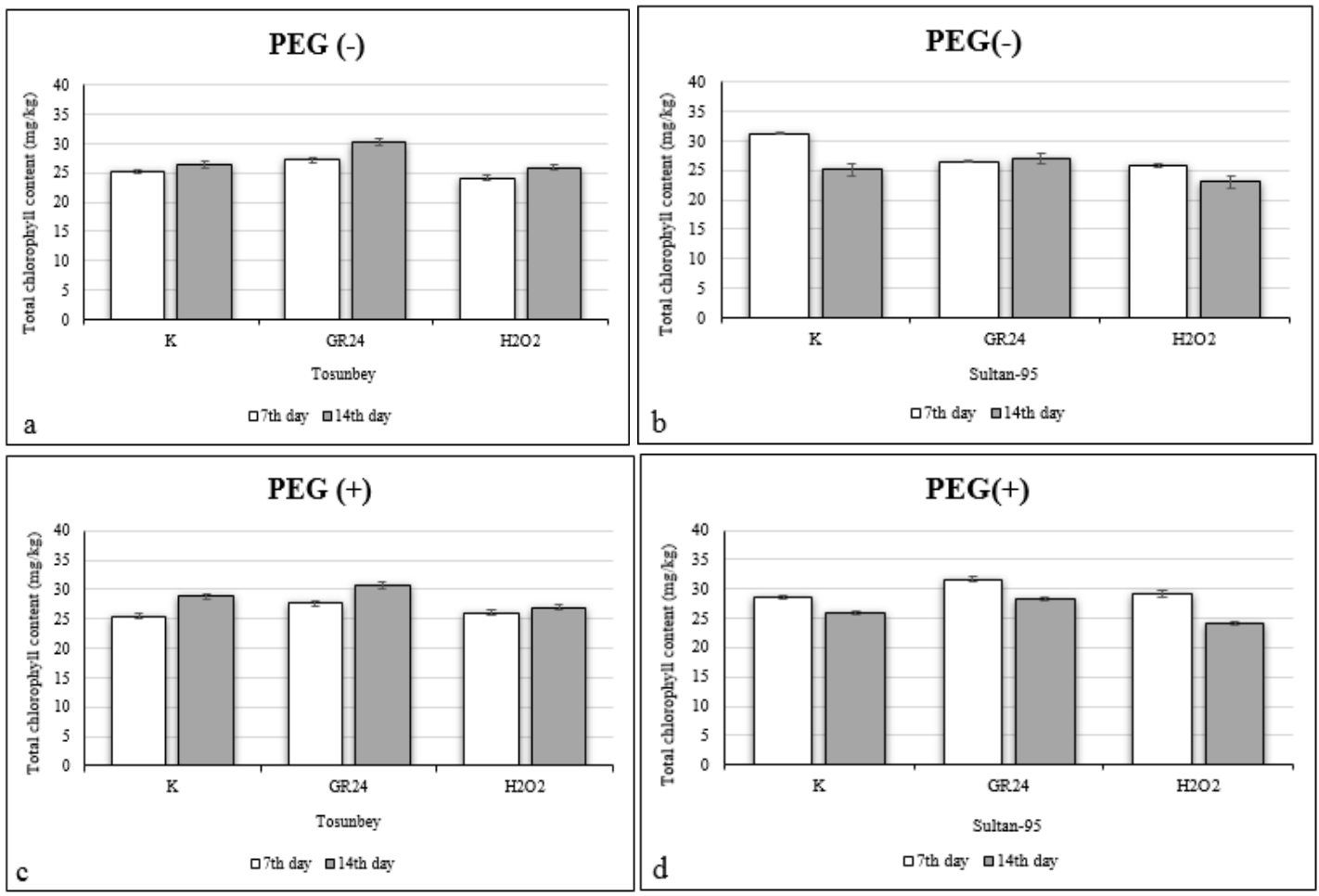

Figure 9. Effects of foliar GR24 and $\mathrm{H}_{2} \mathrm{O}_{2}$ treatments on total chlorophyll contents in 7d- and14d-old wheat seedlings under control [PEG (-)] and drought treatment [PEG (+)] conditions (TK: Tosunbey control, TGR24: Tosunbey GR24, $\mathrm{TH}_{2} \mathrm{O}_{2}$ : Tosunbey $\mathrm{H}_{2} \mathrm{O}_{2}$, SK: Sultan-95 control, SGR24: Sultan-95 GR24, $\mathrm{SH}_{2} \mathrm{O}_{2}$ : Sultan-95 $\mathrm{H}_{2} \mathrm{O}_{2}$ ).

\subsubsection{Total Protein Content}

While the total protein content of the Tosunbey variety increased by $23 \%$ and $108 \%$, respectively, on the $7^{\text {th }}$ and $14^{\text {th }}$ days of the control group with GR24 priming, it increased by $49 \%$ and $1 \%$ in the drought group, respectively. In this cultivar, the amount of protein increased by $63 \%$ and $50 \%$ on the $7^{\text {th }}$ and $14^{\text {th }}$ days in the control group with $\mathrm{H}_{2} \mathrm{O}_{2}$ priming, respectively. However, in the drought group, it increased by $51 \%$ on the $7^{\text {th }}$ day and decreased by $18 \%$ on the 14 th day (Figure 12a-b).

In the Sultan-95 variety, the amount of protein increased by $11 \%$ and $1 \%$, respectively, on the $7^{\text {th }}$ and $14^{\text {th }}$ days of the control group with GR24 priming, while it decreased by $8 \%$ on the $7^{\text {th }}$ day in the drought group and increased by $39 \%$ on the 14th day. In this cultivar, the amount of protein with $\mathrm{H}_{2} \mathrm{O}_{2}$ priming decreased by $2 \%$ and $45 \%$ on $7^{\text {th }}$ and $14^{\text {th }}$ days in the control group, respectively. However, in the drought group, it increased by $35 \%$ and $14 \%$ on days 7 and 14, respectively (Figure 12c-d) 

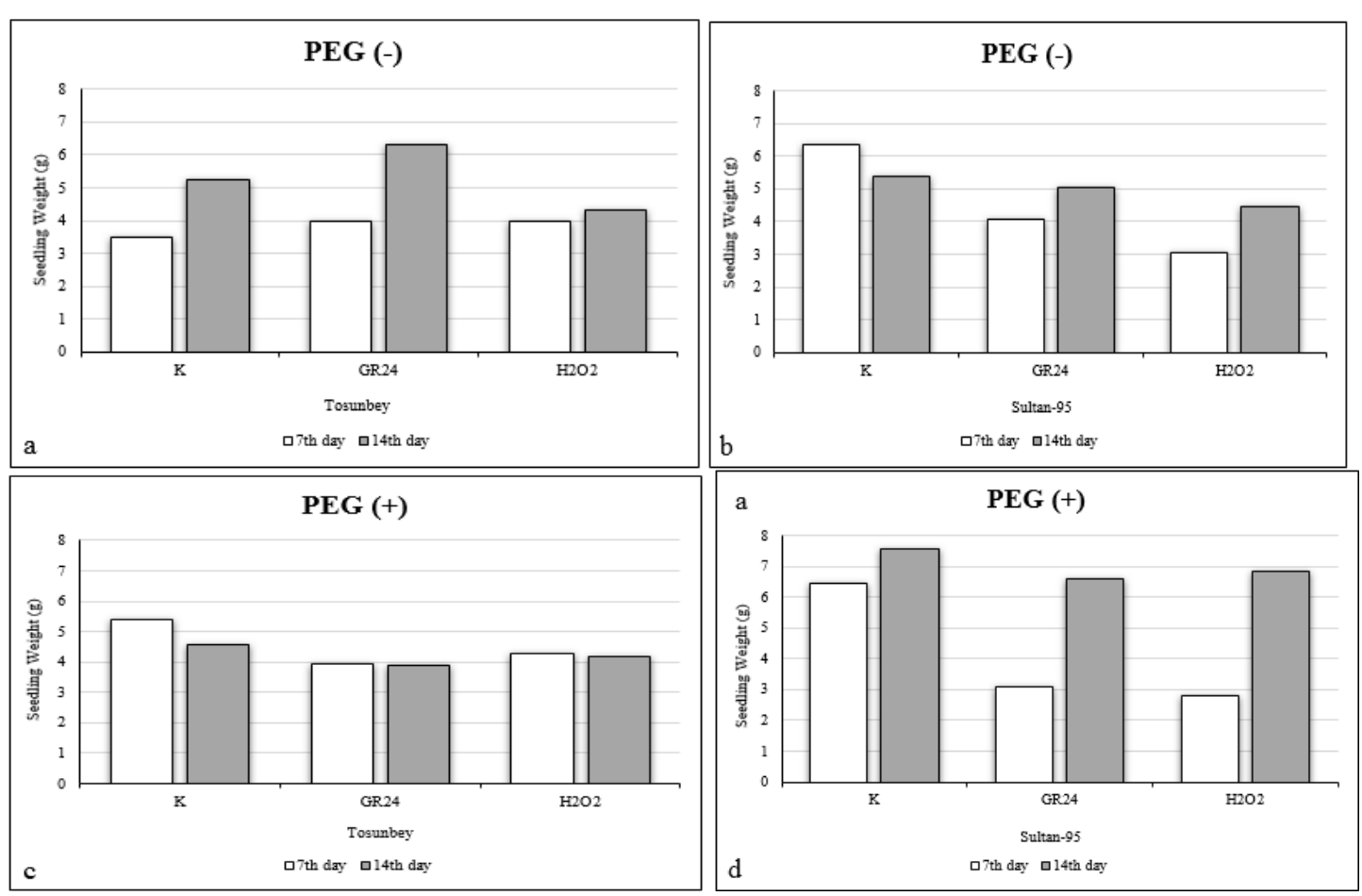

Figure 10. Effects of foliar GR24 and $\mathrm{H}_{2} \mathrm{O}_{2}$ treatments on seedling weight in 7d- and14d-old wheat seedlings under control [PEG (-)] and drought treatment [PEG (+)] conditions (TK: Tosunbey control, TGR24: Tosunbey GR24, $\mathrm{TH}_{2} \mathrm{O}_{2}$ : Tosunbey $\mathrm{H}_{2} \mathrm{O}_{2}$, SK: Sultan-95 control, SGR24: Sultan-95 GR24, $\mathrm{SH}_{2} \mathrm{O}_{2}$ : Sultan-95 $\mathrm{H}_{2} \mathrm{O}_{2}$ ).
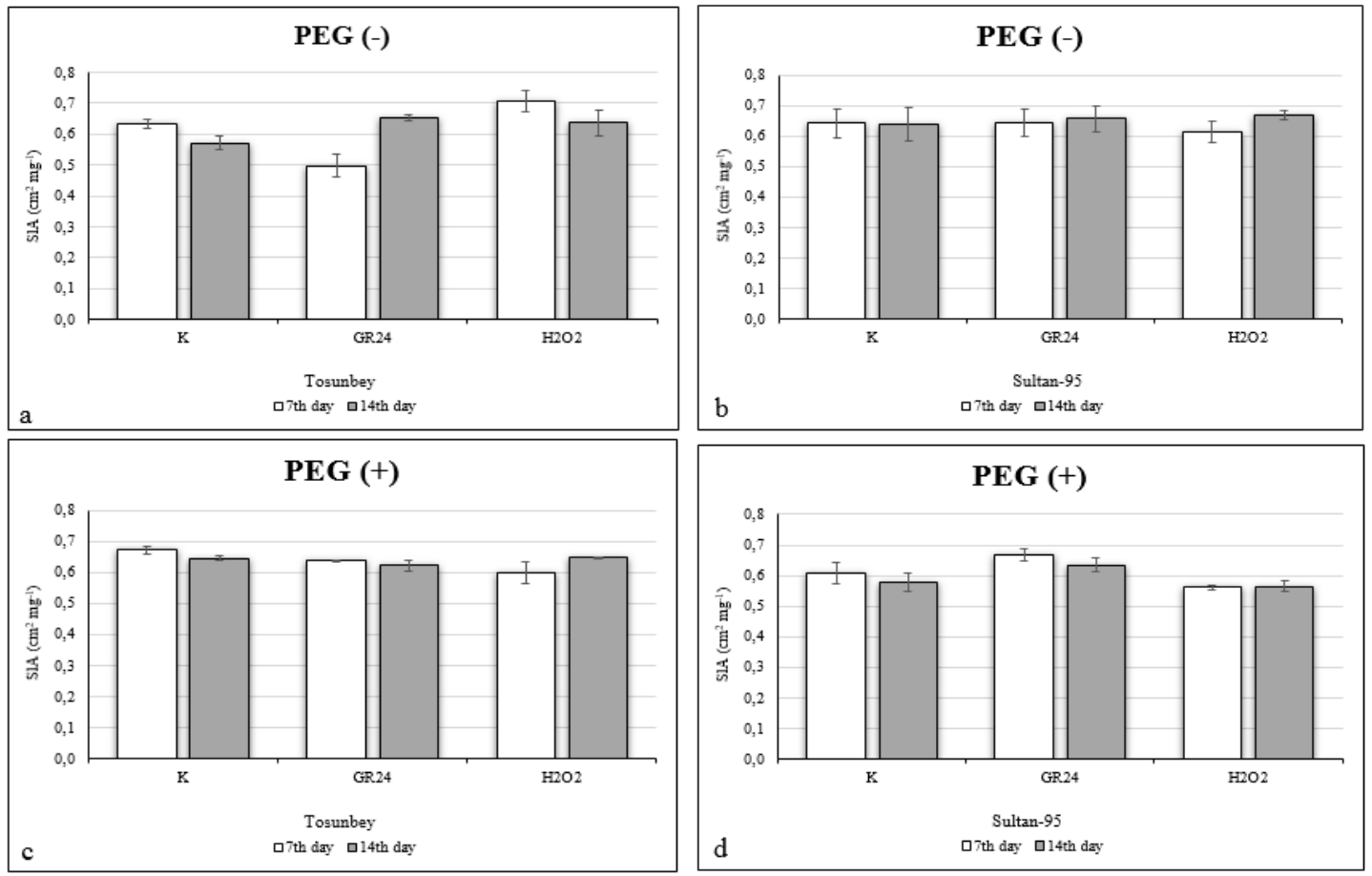

Figure 11. Effects of foliar GR24 and $\mathrm{H}_{2} \mathrm{O}_{2}$ treatments on SLA in 7d- and14d-old wheat seedlings under control [PEG (-)] and drought treatment [PEG $(+)$ ] conditions (TK: Tosunbey control, TGR24: Tosunbey GR24, $\mathrm{TH}_{2} \mathrm{O}_{2}$ : Tosunbey $\mathrm{H}_{2} \mathrm{O}_{2}$, SK: Sultan-95 control, SGR24: Sultan-95 GR24, $\mathrm{SH}_{2} \mathrm{O}_{2}$ : Sultan-95 $\mathrm{H}_{2} \mathrm{O}_{2}$ ).

10 | P a g e

www.iiste.org 

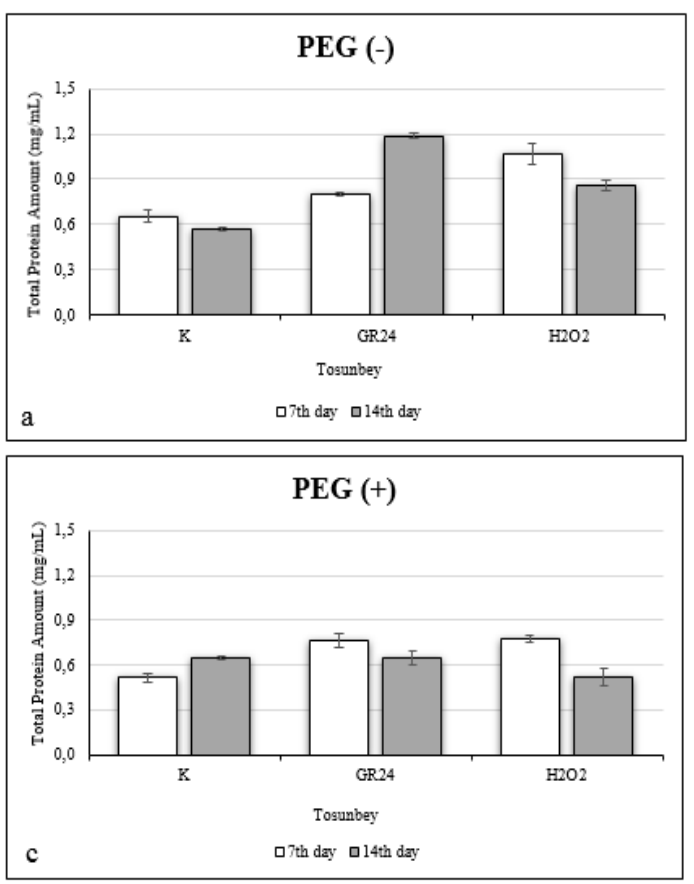
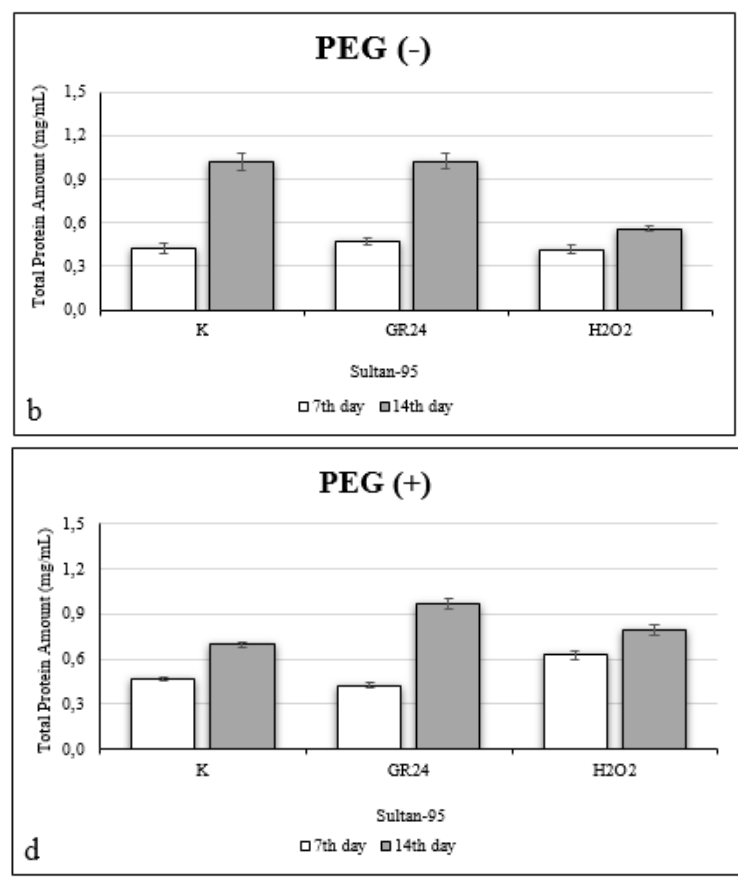

Figure 12. Effects of foliar GR24 and $\mathrm{H}_{2} \mathrm{O}_{2}$ treatments on SLA in 7d- and14d-old wheat seedlings under control [PEG (-)] and drought treatment [PEG (+)] conditions (TK: Tosunbey control, TGR24: Tosunbey GR24, $\mathrm{TH}_{2} \mathrm{O}_{2}$ : Tosunbey $\mathrm{H}_{2} \mathrm{O}_{2}$, SK: Sultan-95 control, SGR24: Sultan-95 GR24, $\mathrm{SH}_{2} \mathrm{O}_{2}$ : Sultan-95 $\mathrm{H}_{2} \mathrm{O}_{2}$ ).

\subsection{Discussion}

In the last decade, there have been numerous reports of newly discovered carotenoid derivative strigolactones (SLs) reducing the negative effects of stress on plants under drought stress (Min et al., 2019; Omoarelojie et al., 2020; Sedaghat et al., 2017; Ni et al., 2020; Lin et al., 2020). Accordingly, foliar application of GR24 can reduce the negative effects of drought stress by increasing the amount of chlorophyll in the grape (Min et al., 2019), can increase seed germination and seedling development in lupine (Omoarelojie et al., 2020), and can also increase tolerance to drought stress in wheat (Sedeghat et al., 2017). In addition, the application of GR24 $\left(0,18 \mu \mathrm{ML}^{-1}\right)$ to colza seed can significantly increase lateral root growth, shoot growth, and root/shoot ratio in seedlings. Furthermore, it has been shown that exogenous SL application can alleviate the negative impact of drought stress on the growth of colza seed seedlings (Lin et al., 2020).

Similarly, our results showed that the application of GR24 priming in drought-resistant cv. Tosunbey and drought-sensitive cv. Sultan-95 increases root lengths. The highest increase was obtained with $1 \mathrm{~h}$ GR24 application in Tosunbey variety and $24 \mathrm{~h}$ in Sultan-95 variety. Increased the shoot length in these varieties of $24 \mathrm{~h} \mathrm{GR} 24$ application. In the pot trial, it was determined that all GR24 applications in the control group increased the root length. Contrary to other studies, our results showed that exogenous GR24 decreased root and shoot lengths in wheat under PEG-induced osmotic stress. Exogenous GR24 has been shown to decrease the endogenous auxin level in rapeseed by $52 \%$ and $75 \% 12$ hours and 1 day after administration (Ni et al., 2020). This may be explanatory for the increase in root length of control plants in the pot trial. However, more detailed research is needed for growth inhibition in seedlings under drought.

It was determined that all GR24 applications in Tosunbey increased the amount of chlorophyll in both petri and pot experiments. In the drought-sensitive variety Sultan-95, it was determined that the amount of chlorophyll decreased in the petri and increased in the pot trial. These results are consistent with those in grape (Min et al., 2019), lupine (Omoarelojie et al., 2020), and rapeseed (Lin et al., 2020). 
On the other hand, a decrease in biomass has been reported in wheat seedlings under drought stress (Shan et al., 2018). $1 \mathrm{~h}$ and $12 \mathrm{~h}$ GR24 priming applications in Tosunbey, $24 \mathrm{~h}$, and $48 \mathrm{~h}$ GR2 4 priming applications in Sultan-95 increased the biomass. Interestingly, at the end of the pot trial, biomass decreased due to osmotic stress-dependent drought. According to the biomass results, GR24 treatment improved the negative effects of drought in wheat varieties exposed to drought stress. Moreover, GR24 priming treatments did not increase the germination percentage.

Specific leaf area (SLA) is the ratio of leaf biomass to leaf area and is a measure of plant strategy in response to environmental changes (Zhou et al., 2020). Our study results showed that SLA increased with GR24 priming and only with GR24 in Sultan-95 and Tosunbey seedlings under drought stress. While the total protein content increased with all GR24 priming applications in Tosunbey variety, it increased with only $12 \mathrm{~h}$ GR24 in Sultan-95. In the pot trial, it was determined that the total amount of protein increased on the $7^{\text {th }}$ day and at the end of the experiment, respectively, in Tosunbey and Sultan95 seedlings under drought stress with foliar GR24 treatment. These results are consistent with those for data of rapeseed under drought stress (Lin et al., 2020).

Hydrogen peroxide $\left(\mathrm{H}_{2} \mathrm{O}_{2}\right)$ is normally a toxic molecule to the cell, however, at low concentrations acts as a signal molecule. It was showed that priming treatment or exogenous treatment of $\mathrm{H}_{2} \mathrm{O}_{2}$ in plants exposed to drought stress improves the harmful effects of stress. (Shang et al., 2020; Iqbal et al, 2018; Habib et al., 2020). Although our results show that root lengths increased in both varieties with $\mathrm{H}_{2} \mathrm{O}_{2}$ priming, it was determined that shoot lengths increased only in Tosunbey effectively. These results are consistent with the results from mung bean seeds under drought stress (Nawaz et al., 2021). Pot experiment results indicated that increases in root and shoot lengths were inhibited by osmotic stress caused by PEG. These results are not compatible with $\mathrm{H}_{2} \mathrm{O}_{2}$ priming results obtained in rice (Shang et al., 2020), quinoa (Iqbal et al., 2018), and wheat (Habib et al., 2020) under drought stress with $\mathrm{H}_{2} \mathrm{O}_{2}$. Additionally, $\mathrm{H}_{2} \mathrm{O}_{2}$ priming increased the amount of chlorophyll in Tosunbey but foliar $\mathrm{H}_{2} \mathrm{O}_{2}$ treatment decreased it. Further, seed germination increased with $24 \mathrm{~h} \mathrm{H}_{2} \mathrm{O}_{2}$ priming in Sultan-95.

These results indicate that the drought-tolerant variety shows better growth than the sensitive variety. In fact, all $\mathrm{H}_{2} \mathrm{O}_{2}$ priming treatments increased biomass in Tosunbey, while Sultan-95 is limited to $24 \mathrm{~h}$ and $48 \mathrm{~h}$. On the other hand, it was determined that osmotic stress decreased with foliar $\mathrm{H}_{2} \mathrm{O}_{2}$ treatments in the pot experiment. In addition, $\mathrm{H}_{2} \mathrm{O}_{2}$ priming and foliar $\mathrm{H}_{2} \mathrm{O}_{2}$ treatments appear to be effective in increasing the SLA of Tosunbey variety. In this context, it was found that the total protein content increased in both varieties with $\mathrm{H}_{2} \mathrm{O}_{2}$ priming, with foliar $\mathrm{H}_{2} \mathrm{O}_{2}$ treatment increased it only in the drought group.

Based on our results, it can be said growth parameters and total protein to remedy the harmful effect of PEG-induced osmotic stress showed that foliar GR24 is effective in both wheat varieties, while foliar $\mathrm{H}_{2} \mathrm{O}_{2}$ is effective only in the Tosunbey variety. Accordingly, our results indicate that GR24 priming promotes growth in both varieties, while $\mathrm{H}_{2} \mathrm{O}_{2}$ priming increases growth in Tosunbey varieties.

\section{Conclusion}

In this study, results were obtained that GR24 applications, a synthetic SL, support growth and yield in drought-resistant Tosunbey variety. The failure to achieve similar results in $\mathrm{H}_{2} \mathrm{O}_{2}$ applications may be due to the phytohormonal nature of GR24 or the concentration of $\mathrm{H}_{2} \mathrm{O}_{2}$. For this reason, new research is needed on the relationship between GR24 and other phytohormones and on the different concentrations of $\mathrm{H}_{2} \mathrm{O}_{2}$.

\section{Acknowledgements}

The authors would like to thank MSc Gamze BALTACIER for their technical assistance in the analysis phase of the article.

\section{References}

Abid, M., Ali, S., Qi, L. K., Zahoor, R., Tian, Z., Jiang, D., \& Dai, T. (2018). Physiological and biochemical changes during drought and recovery periods at tillering and jointing stages in wheat (Triticum aestivum L.). Scientific reports, 8(1), 1-15.

Apel, K., \& Hirt, H. (2004). Reactive oxygen species: metabolism, oxidative stress, and signal transduction. Annu. Rev. Plant Biol., 55, 373-399.

12 | P a g e

www.iiste.org 
Arıcan, E. S. (2019). Ekmeklik Buğday Çeşitlerinde Ardışık Hidrojen Peroksit Uygulamalarının Tuz Stresi Toleransı Üzerine Etkileri (Master's thesis, Namık Kemal Üniversitesi).

Asada, K. (2006). Production and scavenging of reactive oxygen species in chloroplasts and their functions. Plant physiology, 141(2), 391-396.

Baltacıer, G., \& Acar, O. (2019). Kuraklık stresi altındaki iki buğday varyetesinde Rosa canina L. ekstraktının antioksidan aktivite üzerine etkileri (Master's thesis, Çanakkale Onsekiz Mart Üniversitesi).

Bradford, M. M. (1976). A rapid and sensitive method for the quantitation of microgram quantities of protein utilizing the principle of protein-dye binding. Analytical biochemistry, 72(1-2), 248254.

Caverzan, A., Casassola, A., \& Brammer, S. P. (2016). Antioxidant responses of wheat plants under stress. Genetics and molecular biology, 39(1), 1-6.

Cummins, A. G., \& Roberts-Thomson, I. C. (2009). Prevalence of celiac disease in the Asia-Pacific region. Journal of gastroenterology and hepatology, 24(8), 1347-1351.

FAO (Food and Agriculture Organization). 2018. http://www.fao.org/faostat/en/\#data/QC

Fazeli, F., Ghorbanli, M., \& Niknam, V. (2007). Effect of drought on biomass, protein content, lipid peroxidation and antioxidant enzymes in two sesame cultivars. Biologia Plantarum, 51(1), 98103.

Foyer, C. H., Lopez-Delgado, H., Dat, J. F., \& Scott, I. M. (1997). Hydrogen peroxide-and glutathione-associated mechanisms of acclimatory stress tolerance and signaling. Physiol.Plant., 100(2), 241-254.

H Abd El Baky, H., A Nofal, O., \& S El Baroty, G. (2016). Enhancement of antioxidant enzymes activities, drought stress tolerances and quality of potato plants as response to algal foliar application. Recent patents on food, nutrition \& agriculture, 8(1), 70-77.

Habib, N., Ali, Q., Ali, S., Javed, M. T., Zulqurnain Haider, M., Perveen, R., \& Bin-Jumah, M. (2020). Use of nitric oxide and hydrogen peroxide for better yield of wheat (Triticum aestivum L.) under water deficit conditions: growth, osmoregulation, and antioxidative defense mechanism. Plants, 9(2), 285.

Haider, I., Akmal, M., Shakeel, M. T., Ahmad, S., Ahmad, N., Hussain, S., \& Ali, M. A. (2019). Improving Antioxidant Defense in Plants Through Seed Priming and Seedling Pretreatment. In Priming and Pretreatment of Seeds and Seedlings (pp. 595-604). Springer, Singapore.

Hasanuzzaman, M., Al Mahmud, J., Anee, T. I., Nahar, K., \& Islam, M. T. (2018). Drought stress tolerance in wheat: omics approaches in understanding and enhancing antioxidant defense. Abiotic stress-mediated sensing and signaling in plants: an omics perspective, 267-307.

Hassan, N., Ebeed, H., \& Aljaarany, A. (2020). Exogenous application of spermine and putrescine mitigate adversities of drought stress in wheat by protecting membranes and chloroplast ultrastructure. Physiology and Molecular Biology of Plants, 26(2), 233-245.

Iqbal, H., Yaning, C., Waqas, M., Shareef, M., \& Raza, S. T. (2018). Differential response of quinoa genotypes to drought and foliage-applied $\mathrm{H}_{2} \mathrm{O}_{2}$ in relation to oxidative damage, osmotic adjustment and antioxidant capacity. Ecotoxicology and environmental safety, 164, 344-354. 
Kaur, S., Samant, G. V., Pramanik, K., Loscombe, P. W., Pendrak, M. L., Roberts, D. D., \& Ramchandran, R. (2008). Silencing of directional migration in roundabout4 knockdown endothelial cells. BMC cell biology, 9(1), 1-12.

Kohlen, W., Charnikhova, T., Liu, Q., Bours, R., Domagalska, M. A., Beguerie, S., \& Ruyter-Spira, C. (2011). Strigolactones are transported through the xylem and play a key role in shoot architectural response to phosphate deficiency in nonarbuscular mycorrhizal host Arabidopsis. Plant Physiol., 155(2), 974-987.

Küçükkarakaş, S. (2017). Bazı tritikale ( $x$ triticosecale) genotiplerinde hidrojen peroksit ön uygulamasıyla tuz stresinin meydana getirdiği oksidatif hasarın giderilmesinde süperoksit dismutaz enziminin işlevi (Master's thesis, Namık Kemal Üniversitesi).

Laxa, M., Liebthal, M., Telman, W., Chibani, K., \& Dietz, K. J. (2019). The role of the plant antioxidant system in drought tolerance. Antioxidants, 8(4), 94.

Lin, W. A. N., Zhang-kai, L. I., Su, L. I., Li-xin, L. I. U., Ni, M. A., \& Chun-lei, Z. H. A. N. G. (2020). Alleviation effects of exogenous strigolactone on growth of Brassica napus L. seedling under drought stress. Chinese Journal of Oll Crop Sciences, 42(3), 461.

Liu, J., Hasanuzzaman, M., Wen, H., Zhang, J., Peng, T., Sun, H., \& Zhao, Q. (2019). High temperature and drought stress cause abscisic acid and reactive oxygen species accumulation and suppress seed germination growth in rice. Protoplasma, 256(5), 1217-1227.

Min, Z., Li, R., Chen, L., Zhang, Y., Li, Z., Liu, M., \& Fang, Y. (2019). Alleviation of drought stress in grapevine by foliar-applied strigolactones. Plant Physiology and Biochemistry, 135, 99-110.

Nawaz, H., Hussain, N., Ahmed, N., \& Javaiz, A. L. A. M. (2021). Efficiency of seed bio-priming technique for healthy mungbean productivity under terminal drought stress. Journal of Integrative Agriculture, 20(1), 87-99.

Ni, M. A., Lin, W. A. N., Wei, Z. H. A. O., Liu, H. F., Jun, L. I., \& Zhang, C. L. (2020). Exogenous strigolactones promote lateral root growth by reducing the endogenous auxin level in rapeseed. Journal of Integrative Agriculture, 19(2), 465-482.

Omoarelojie, L. O., Kulkarni, M. G., Finnie, J. F., Pospíšil, T., Strnad, M., \& Van Staden, J. (2020). Synthetic strigolactone (rac-GR24) alleviates the adverse effects of heat stress on seed germination and photosystem II function in lupine seedlings. Plant Physiology and Biochemistry, 155, 965-979.

Othmani, A., Ayed, S., Bezzin, O., Farooq, M., Ayed-Slama, O., Slim-Amara, H., \& Younes, M. B. (2020). Effect of silicon supply methods on durum wheat (Triticum durum Desf.) response to drought stress. Silicon, 1-11.

Önay, E. (2019). Strigolaktonun tuz stresine toleranslı ve duyarlı buğday çeşitlerinde askorbatglutatyon döngüsü enzim sishootine etkisi (Master's thesis, Namık Kemal Üniversitesi).

Özel, Ş. G. (2018). Strigolakton uygulamasıyla tuz stresine karşı kum zambağı bitkisinin toleransının arttırılmasında antioksidan enzimlerin işlevi (Master's thesis, Namık Kemal Üniversitesi).

Peryea, F. J., \& Kammereck, R. (1997). Use of Minolta SPAD-502 chlorophyll meter to quantify the effectiveness of mid-summer trunk injection of iron on chlorotic pear trees. Journal of plant nutrition, 20(11), 1457-1463. 
Saboor, A., Mustafa, G., Arshad, M., Ahmad, M., Hussain, S., Ahmed, N., \& Ali, M. A. (2019). Seed priming and metal/metalloid stress tolerance in plants. In Priming and pretreatment of seeds and seedlings (pp. 287-311). Springer, Singapore.

Sedaghat, M., Sarvestani, Z. T., Emam, Y., Bidgoli, A. M., \& Sorooshzadeh, A. (2020). Foliarapplied GR24 and salicylic acid enhanced wheat drought tolerance. Russian J. of Plant Physiology, 67(4), 733-739.

Sedaghat, M., Tahmasebi-Sarvestani, Z., Emam, Y., \& Mokhtassi-Bidgoli, A. (2017). Physiological and antioxidant responses of winter wheat cultivars to strigolactone and salicylic acid in drought. Plant Physiology and Biochemistry, 119, 59-69.

Shan, C., Zhang, S., \& Ou, X. (2018). The roles of H $2 \mathrm{~S}$ and H 2 O 2 in regulating AsA-GSH cycle in the leaves of wheat seedlings under drought stress. Protoplasma, 255(4), 1257-1262.

Sohag, A. A. M., Tahjib-Ul-Arif, M., Brestic, M., Afrin, S., Sakil, M. A., Hossain, M. T., \& Hossain, M. A. (2020). Exogenous salicylic acid and hydrogen peroxide attenuate drought stress in rice. Plant, Soil and Environment, 66(1), 7-13.

Steward F. C., 1983. Plant Physiology, Academic Press, New York and London, 797 p.

Wang, X., Li, Q., Xie, J., Huang, M., Cai, J., Zhou, Q., \& Jiang, D. (2021). Abscisic acid and jasmonic acid are involved in drought priming-induced tolerance to drought in wheat. The Crop $J ., 9(1), 120-132$.

Wang, X., Zhang, J., Song, J., Huang, M., Cai, J., Zhou, Q., \& Jiang, D. (2020). Abscisic acid and hydrogen peroxide are involved in drought priming-induced drought tolerance in wheat (Triticum aestivum L.). Plant Biology, 22(6), 1113-1122.

Wilson, P. J., Thompson, K. E. N., \& Hodgson, J. G. (1999). Specific leaf area and leaf dry matter content as alternative predictors of plant strategies. New phytologist, 143(1), 155-162.

Yadav, T., Kumar, A., Yadav, R. K., Yadav, G., Kumar, R., \& Kushwaha, M. (2020). Salicylic acid and thiourea mitigate the salinity and drought stress on physiological traits governing yield in pearl millet-wheat. Saudi Journal of Biological Sciences, 27(8), 2010-2017.

Zhang, T., Fan, S., Xiang, Y., Zhang, S., Wang, J., \& Sun, Q. (2020). Non-destructive analysis of germination percentage, germination energy and simple vigour index on wheat seeds during storage by Vis/NIR and SWIR hyperspectral imaging. Spectrochimica Acta Part A: Mol. Biomol. Spec., 239, 118488.

Zhou, H., Zhou, G., He, Q., Zhou, L., Ji, Y., \& Zhou, M. (2020). Environmental explanation of maize specific leaf area under varying water stress regimes. Environmental and Experimental Botany, 171, 103932. 